\title{
Rate and pattern of epithelial cell proliferation in ulcerative colitis
}

\author{
E P SERAFINI, A P K IRK, * AND T J CH•AMBERS \\ From the Department of Experimental Pathology, St. Bartholomew's Hospital Medical College, \\ and St. Mark's Hospital, London
}

SUMMARY We investigated the pattern of proliferation of epithelial cells in rectal mucosa taken from normal individuals and patients with ulcerative colitis by incubating mucosa with tritiated thymidine in vitro and processing for autoradiography. We found that patients with ulcerative colitis in remission showed a proliferative pattern similar to that seen in both regenerating and 'precancerous' mucosa. Patients with a short history were as likely to show this pattern as those with a long history, and this shows that the abnormal pattern does not signify impending malignant change. We also found that mucosa from patients with ulcerative colitis in remission showed an increased proportion of cells synthesising DNA, a proportion surprisingly close to that seen in an active phase; this suggests that the abnormal pattern seen in remission is the pattern of a regenerating mucosa. We feel that this high rate of mucosal turnover, sustained not just during clinically active disease but throughout remission, leads to the increased incidence of carcinoma and to the development of carcinoma in flat mucosa.

Patients with ulcerative colitis have an increased risk of developing adenocarcinoma of the large intestine. The risk only becomes clinically significant after many years with the disease, and one of the major problems in the management of patients with ulcerative colitis is how to reconcile the conflicting aims of preserving the patient's large intestine for as long as possible and removing it before carcinoma develops. Some clinicians use length of history as a guide. However, the interval between disease onset and the development of cancer varies so much between individuals that to excise the colorectum before the risk of carcinoma becomes significant is to do so many years earlier than necessary for most patients. An alternative approach relies on the observation that dysplasia often develops before carcinoma, and dysplasia can be monitored by colorectal biopsy. ${ }^{1}$ This approach allows most patients to keep their large bowel for longer, but, because dysplasia is a patchy change, it may not be detected, and a proportion of patients managed in this way develop a carcinoma.

Received for publication 20 January 1981
Lipkin $^{2}$ found an abnormal pattern of deoxyribonucleic acid (DNA) synthesis when he cultured mucosa from patients with polyposis coli and dimethylhydrazine-treated mice. He suggested that this altered pattern was a premalignant change. Although the rate and pattern of cell proliferation has been measured in the mucosa of patients with active ulcerative colitis, ${ }^{34}$ the pattern of DNA synthesis has not been investigated in ulcerative colitis during remission. In view of the observations of Lipkin $^{2}$ we felt that there may be alterations in the pattern of cell proliferation in ulcerative colitis that may be a useful indicator of the development of malignant change.

\section{Methods}

Rectal biopsies were obtained from 26 patients with ulcerative colitis attending St. Mark's Hospital as outpatients. Their age, sex, duration, and extent of disease are shown in Table 1. Disease activity was determined both clinically and histologically. The clinical disease index was based on symptoms, signs, sigmoidoscopic appearance, blood count, and erythrocyte sedimentation rate. ${ }^{5}$ A biopsy was said to be histologically in remission 
Table 1 Clinical details and histology of colitic patients studied

\begin{tabular}{|c|c|c|c|c|c|c|c|}
\hline \multirow[t]{2}{*}{ Patient } & \multirow{2}{*}{$\begin{array}{l}\text { Age } \\
(y r)\end{array}$} & \multirow[t]{2}{*}{ Sex } & \multirow[t]{2}{*}{ Histology } & \multirow{2}{*}{$\begin{array}{l}\text { Clinical } \\
\text { picture }\end{array}$} & \multicolumn{2}{|l|}{ Disease } & \multirow[t]{2}{*}{ Medication } \\
\hline & & & & & Extent & $\begin{array}{l}\text { Duration } \\
(y r)\end{array}$ & \\
\hline $\begin{array}{r}1 \\
2 \\
3 \\
4 \\
5 \\
6 \\
7 \\
8 \\
9 \\
10 \\
11 \\
12 \\
13 \\
14 \\
15 \\
16 \\
17 \\
18 \\
19 \\
20 \\
21 \\
22 \\
23 \\
24 \\
25 \\
26\end{array}$ & $\begin{array}{l}62 \\
51 \\
57 \\
58 \\
69 \\
51 \\
45 \\
40 \\
26 \\
44 \\
49 \\
69 \\
19 \\
60 \\
44 \\
29 \\
70 \\
47 \\
58 \\
49 \\
37 \\
46 \\
26 \\
33 \\
23 \\
69\end{array}$ & $\begin{array}{l}\mathbf{M} \\
\mathbf{F} \\
\mathbf{M} \\
\mathbf{M} \\
\mathbf{M} \\
\mathbf{F} \\
\mathbf{M} \\
\mathbf{M} \\
\mathbf{F} \\
\mathbf{F} \\
\mathbf{M} \\
\mathbf{F} \\
\mathbf{M} \\
\mathbf{M} \\
\mathbf{M} \\
\mathbf{F} \\
\mathbf{M} \\
\mathbf{M} \\
\mathbf{F} \\
\mathbf{M} \\
\mathbf{M} \\
\mathbf{F} \\
\mathbf{M} \\
\mathbf{M} \\
\mathbf{F} \\
\mathbf{F}\end{array}$ & $\begin{array}{l}\mathbf{R} \\
\mathbf{R} \\
\mathbf{R} \\
\mathbf{R} \\
\mathbf{R} \\
\mathbf{R} \\
\mathbf{R} \\
\mathbf{R} \\
\mathbf{R} \\
\mathbf{R} \\
\mathbf{R} \\
\mathbf{R} \\
\mathbf{R} \\
\mathbf{R} \\
\mathbf{R} \\
\mathbf{R} \\
\mathbf{R} \\
\mathbf{R} \\
\mathbf{A} \\
\mathbf{A} \\
\mathbf{A} \\
\mathbf{A} \\
\mathbf{A} \\
\mathbf{A} \\
\mathbf{A} \\
\mathbf{A}\end{array}$ & $\begin{array}{l}\mathbf{R} \\
\mathbf{R} \\
\mathbf{A} \\
\mathbf{A} \\
\mathbf{R} \\
\mathbf{R} \\
\mathbf{R} \\
\mathbf{R} \\
\mathbf{R} \\
\mathbf{R} \\
\mathbf{A} \\
\mathbf{R} \\
\mathbf{R} \\
\mathbf{R} \\
\mathbf{A} \\
\mathbf{R} \\
\mathbf{A} \\
\mathbf{R} \\
\mathbf{A} \\
\mathbf{A} \\
\mathbf{A} \\
\mathbf{A} \\
\mathbf{A} \\
\mathbf{A} \\
\mathbf{A} \\
\mathbf{A}\end{array}$ & $\begin{array}{l}\text { T } \\
\text { T } \\
\mathbf{D} \\
\mathbf{T} \\
\mathbf{T} \\
\mathbf{D} \\
\mathbf{T} \\
\mathbf{T} \\
\mathbf{T} \\
\mathbf{D} \\
\mathbf{T} \\
\mathbf{T} \\
\mathbf{T} \\
\mathbf{T} \\
\mathbf{D} \\
\mathbf{D} \\
\mathbf{D} \\
\mathbf{D} \\
\mathbf{D} \\
\mathbf{T} \\
\mathbf{D} \\
\mathbf{D} \\
\mathbf{D} \\
\mathbf{T} \\
\mathbf{T} \\
\mathbf{T}\end{array}$ & $\begin{array}{r}11 \\
11 \\
11 \\
3 \\
12 \\
4 \\
13 \\
21 \\
10 \\
3 \\
17 \\
12 \\
7 \\
11 \\
8 \\
7 \\
15 \\
19 \\
18 \\
1 \\
5 \\
26 \\
2 \\
9 \\
5 \\
8\end{array}$ & $\begin{array}{l}\text { Sal } \\
\text { Sal } \\
\text { St+Sal } \\
\text { St+Sal } \\
\text { St+Sal } \\
\text { Sal } \\
\text { St } \\
\text { St } \\
\text { St/Sal+Aza } \\
\text { St/Sal+Aza }+ \text { Aza } \\
\text { St/Sal+Aza }+ \text { Aza } \\
\text { Sal } \\
\text { St+Sal } \\
\text { St/Sal+Aza } \\
\text { Sal } \\
\text { St } \\
\text { St } \\
\text { St+Sal } \\
\text { St+Sal } \\
\text { St+Sal } \\
\text { Sal } \\
\text { St+Sal } \\
\text { St+Sal } \\
\text { St/Sal+Aza } \\
\text { St } \\
\text { Sal }\end{array}$ \\
\hline
\end{tabular}

D: distal colitis. T: total colitis. Sal. salazosulphapyridin. St : steroids. Aza: azathioprine. A: active colitis. R: colitis in remission.

only if there were no crypt abscesses, no intraepithelial polymorphs, no increase in polymorphs in the lamina propria, and none on the luminal surface. The epithelium always showed a welldeveloped goblet cell population, with no histological evidence of dysplasia or increased epithelial regenerative activity. Eighteen patients were in histological remission, while eight patients showed active disease (Table 1). Controls were obtained from two patients with functional bowel disease and five patients undergoing surgery for large bowel carcinoma-the mucosa cultured in these cases was far from the malignant growth and there were no polyps in the remaining bowel.

Each biopsy was divided into two fragments: one was fixed in formalin, processed and stained by routine methods, and used for histological assessment of disease activity. The second fragment was washed in several changes of Hank's solution and cut into pieces $3 \mathrm{~mm}$ in diameter. The mucosa was then placed with its epithelial surface uppermost on a stainless steel grid resting in an organ culture dish (Falcon) containing $1 \mathrm{ml}$ of culture medium. This consisted of hepesbuffered medium 199 (Flow) supplemented with $10 \%$ heat-inactivated fetal calf serum (Flow) and containing $10 \mu \mathrm{Ci} / \mathrm{ml}$ " $\mathrm{H}$-thymidine (Amersham
Radiochemicals). The culture medium also contained $100 \mathrm{IU}$ benzylpenicillin per $\mathrm{ml}, 100 \mu \mathrm{g} / \mathrm{ml}$ streptomycin (Glaxo), and $100 \mu \mathrm{g} / \mathrm{ml}$ fungizone (Flow). The mucosa was incubated for six hours in an atmosphere of humidified air at $37^{\circ} \mathrm{C}$. The fragments were then washed in Hank's solution, fixed in Bouin's solution, and embedded in paraffin wax. Multiple sections were cut at a thickness of $4 \mu \mathrm{m}$ and autoradiographs were prepared using Kodak AR 10 stripping film. After exposure for four to five weeks the film was developed, and the sections stained with haematoxylin and eosin and examined by light microscopy. A mean of 7.6 sections was examined for each patient. When the pattern of proliferation was measured, the crypts were divided into three regions using an eyepiece micrometer: lower, middle, and upper thirds. All nuclei with more than 10 grains (background nuclei less than two grains) were scored, and the results expressed as the average number of labelled nuclei in each crypt region. The proliferation index was measured as the percentage of epithelial cells which showed autoradiographic evidence of DNA synthesis. This was determined from a count of at least 1000 cells in each biopsy. The proportion of cells incorporating DNA is a useful measure of the proliferation rate provided that there is no 
difference between the groups in the relative duration of the stages of the cell cycle.

\section{Results}

We found a similar proliferation pattern to that previously reported ${ }^{31}$ in normal mucosa and in mucosa from patients with active ulcerative colitis (Table 2). In normal mucosa proliferative cells were mostly limited to the lower third of the crypts. In active ulcerative colitis an increased proportion of labelled cells appeared higher in the crypt. The distinction is emphasised when the results are expressed as a ratio of cells proliferating in the lower two-thirds to those in the upper third, when the value was 4.2 in normal, and 1.5 in active colitic mucosa. The pattern of proliferation in ulcerative colitis in remission can be seen to be similar to that seen in active ulcerative colitis, and is similar to the pattern described in precancerous mucosa. ${ }^{2}$

To help decide whether this shift from a normal (basal) to a more random distribution of proliferative cells represented an early change in the progression towards malignancy (a 'functional dysplasia') we separated the patients with ulcerative colitis in remission into those with a history of less than 10 years and those with ulcerative colitis for more than 10 years. We found no significant differ- ence between the proliferative patterns in the two groups (Table 3 ). Nor did the pattern seem related to drug therapy or to anatomical extent of disease (Table 3 ).

When we counted the percentage of cells proliferating in the mucosa we found that both active ulcerative colitis and ulcerative colitis in remission showed an increased proliferation index compared with normal $(\mathrm{P}<0.01)$ (Table 4). Indeed, the proliferation index of colitic mucosa in remission was very similar to that seen in active

Table 4 Proportion of cells synthesising DNA in rectal mucosa from patients with ulcerative colitis and normal controls

\begin{tabular}{|c|c|c|c|}
\hline & $\begin{array}{l}\text { Proliferation } \\
\text { index }\end{array}$ & $S E M$ & $\begin{array}{l}\text { Number of } \\
\text { patients }\end{array}$ \\
\hline $\begin{array}{l}\text { Normal } \\
\text { Ulcerative colitis }\end{array}$ & $13 \cdot 1$ & 0.53 & 7 \\
\hline Active & $19 \cdot 0^{*}$ & 0.37 & 8 \\
\hline In histological remission & $17 \cdot 3^{*}$ & $0 \cdot 19$ & 18 \\
\hline $\begin{array}{l}\text { In histological and } \\
\text { sigmoidoscopic remission }\end{array}$ & $18 \cdot 8$ & 0.25 & 11 \\
\hline $\begin{array}{l}\text { In histological remission } \\
\text { but mildly active } \\
\text { sigmoidoscopically }\end{array}$ & $15 \cdot 5$ & 0.47 & 7 \\
\hline $\begin{array}{l}\text { In histological and clinical } \\
\text { remission }\end{array}$ & $.17 \cdot 9$ & $0 \cdot 29$ & 13 \\
\hline $\begin{array}{l}\text { In histological remission } \\
\text { but clinically active }\end{array}$ & 15.9 & 0.4 & 5 \\
\hline
\end{tabular}

${ }^{*} \mathrm{p}<0.001$ when compared with normal.

Table 2 Pattern of DNA synthesis in crypts of patients with ulcerative colitis and normal controls

\begin{tabular}{|c|c|c|c|}
\hline \multirow[b]{3}{*}{$\begin{array}{l}\text { Normal (7) } \\
\text { Active ulcerative colitis (8) } \\
\text { Ulcerative colitis in remission }\end{array}$} & \multicolumn{2}{|c|}{$\begin{array}{l}\text { Number of labelled cells per crypt } \\
( \pm S E M)\end{array}$} & \multirow{2}{*}{$\begin{array}{l}\text { Ratio of } \frac{\text { cells labelled in lower thirds }}{\text { cells labelled in upper third }} \\
( \pm S E M)\end{array}$} \\
\hline & Lower two-thirds & Upper third & \\
\hline & $\begin{array}{ll}6.6 & ( \pm 0.39) \\
4 \cdot 5 & (0 \cdot 14) \\
3.8 & (0.06)\end{array}$ & $\begin{array}{ll}1.5 & (0.05) \\
3.0 & (0 \cdot 14) \\
3 \cdot 2 & (0.06)\end{array}$ & $\begin{array}{ll}4.2 & (0.17) \\
1.5 & (0.05)^{*} \\
1.35 & (0.03) \uparrow\end{array}$ \\
\hline
\end{tabular}

${ }^{*} \mathrm{P}<0.01$ when compared with normal. $\dagger \mathrm{P}<0.001$ when compared with normal.

Table 3 Pattern of proliferation and proliferation index in patients with ulcerative colitis in remission

\begin{tabular}{|c|c|c|c|c|}
\hline & \multirow{2}{*}{$\begin{array}{l}\text { Number of } \\
\text { patients }\end{array}$} & \multicolumn{2}{|c|}{ Proliferative pattern } & $\begin{array}{l}\text { Proliferation index } \\
( \pm S E M)\end{array}$ \\
\hline & & $\left(\begin{array}{l}\text { lower thirds } \\
\text { upper third }\end{array}\right)$ & $( \pm S E M)$ & \\
\hline \multicolumn{5}{|l|}{ Length of history $(\mathrm{yr})$ : } \\
\hline $\begin{array}{l}\text { Less than } 10 \\
\text { More than } 10\end{array}$ & 12 & $\begin{array}{ll}1.35 & (0.06) \\
1.35 & (0.06)\end{array}$ & & $17.9 \quad(0.9)$ \\
\hline More than 10 & 12 & $1.35 \quad(0.06)$ & & $17 \cdot 1 \quad(0 \cdot 2)$ \\
\hline Steroids & 4 & $1 \cdot 1 \quad(0 \cdot 12)$ & & $18.9 \quad(1 \cdot 0)$ \\
\hline Steroids + salazopyrin & 5 & $1.4 \quad(0 \cdot 2)$ & & $17 \cdot 4 \quad(0 \cdot 7)$ \\
\hline Salazopyrin & 5 & $1.6 \quad(0 \cdot 2)$ & & $15.1 \quad(0.65)$ \\
\hline Steroids + salazopyrin + azathioprine & 4 & $1.25 \quad(0.04)$ & & $18 \cdot 8 \quad(0 \cdot 8)$ \\
\hline \multicolumn{5}{|l|}{ Extent of disease: } \\
\hline Distal & 7 & $1.4 \quad(0 \cdot 1)$ & & $18 \cdot 6 \quad(0 \cdot 6)$ \\
\hline Total & 11 & $1.3 \quad(0.05)$ & & $16 \cdot 6 \quad(0 \cdot 2)$ \\
\hline
\end{tabular}


disease. We were a little surprised by these results, as none of the biopsies in the group showed any histological evidence of disease activity. Some, however, showed clinical activity and we separated these and compared proliferative indices of the subgroups so formed (Table 4). The results show that mucosa in histological remission shows at least as high a proliferation index even when these questionably clinically inactive patients are excluded.

\section{Discussion}

In the normal large bowel proliferating cells are confined to the lower two-thirds of the crypts. ${ }^{26}$ ? Their progeny differentiate and migrate up the crypt to be lost from the surface. In contrast, adenomas and carcinomas do not show zones of proliferation and maturation; mitoses are scattered haphazardly throughout the neoplastic epithelium. ${ }^{*}$ The normal pattern of proliferation is also lost in active ulcerative colitis, ${ }^{37}$ in mucosa regenerating after radiotherapy ${ }^{10}$ in polyposis coli ${ }^{2}$ and during dimethylhydrazine treatment of mice ${ }^{2}$ in all of which deoxyribonucleic acid (DNA)synthesising cells are seen high in the crypts. In active ulcerative colitis and after radiotherapy there is increased proliferation to counter an increased rate of cell loss, and, presumably, the more rapid migration of cells up crypts which this increased turnover entails means that cells which are still proliferating are seen higher in the crypt than usual.

Lipkin ${ }^{2}$ found that the first detectable change in rat mucosa during dimethylhydrazine-induced carcinogenesis was a loss of the normal proliferation pattern, and he suggested that the loss of pattern represented an early change in a sequence of changes leading to malignancy. We found a similar extension of DNA-synthesising cells high in the crypt in ulcerative colitis in remission, in the absence of clinical or histological evidence of disease activity. It seemed possible that this change in proliferative pattern similarly represented an early step in neoplastic development, preceding the appearance of dysplasia. If this were the case we would expect to see the pattern more of ten in biopsies from patients with a long history, but we found no such relationship. We also found that the proliferation index in the mucosa of patients with colitis in remission was higher than normal, and this increased proliferation appears to be the most likely explanation for the abnormal proliferative pattern: it is the pattern of regeneration. The abnormal pattern appears not, as suggested by Lipkin, to be a transition stage between normal and malignant tissue; rather, it reflects the increased turnover which itself predisposes to neoplastic development: it is a cause of, not a sign of, neoplastic development.

We were surprised to find evidence of increased proliferation in what appeared to be completely quiescent mucosa. There are several theoretically possible explanations. Increased proliferation infers increased cell death, and it is conceivable that this increased cell death antedates ulcerative colitis, reflecting a constitutionally inadequate mucosa which predisposes the patient to the development of ulcerative colitis. It is also conceivable that the abnormal architecture which persists after episodes of active ulceration may impair mucosal function (just as tissue function is irreversibly impaired by architectural change in cirrhosis and bronchiectasis) and lead to increased cell turnover. The last possibility is that remission in ulcerative colitis is only relative, mucosal damage continuing at a subclinical and subhistological level between relapses.

Whatever the explanation for the increased mucosal turnover in remission, the sustained high proliferation rate probably contributes to the increased incidence of carcinoma in patients with ulcerative colitis, and presumably accounts for the raised incidence of carcinoma even in patients with relatively inactive disease.

The finding of increased proliferation in remission also helps us to understand the differing patterns of neoplastic development in ulcerative colitis and normal patients. Although in the general population there is strong evidence that most carcinomas develop in pre-existing adenomas, ${ }^{11}$ in ulcerative colitis adenomas do not seem to be involved in the evolution of carcinoma; dysplasia and eventually carcinoma develop more often in flat mucosa. ${ }^{1}$ It follows that adenomas are not an early stage in a hypothetical sequence of changes through which cells have to pass to become malignant. Moreover, adenomas do not progress through increasingly severe dysplasias to carcinoma except in the presence of an environmental agent additional to that which causes adenoma formation. ${ }^{12}$ Adenomas do not therefore necessarily either precede or predispose to carcinogenesis. What then is the nature of the relationship between adenomas and carcinomas? Adenomas seem to be 'premalignant' not in the sense that they possess properties approaching those of cancer, but in the same way as the increased proliferation in ulcerative colitis is premalignant: they represent a large volume of 
epithelium (a $2 \mathrm{~cm}$ diameter polyp has about as much epithelium as $80 \mathrm{~cm}^{2}$ of flat mucosa) which has a high proliferation rate (proliferation increases the incidence of neoplasia in the presence of carcinogen). The anatomical form of the adenoma is probably incidental, the sequence of events, including dysplasias, which culminate in malignancy tending to evolve in adenomas because adenomas represent large numbers of proliferating cells. We found a sustained high proliferation index in ulcerative colitis, and, again, this would be expected to increase the chances of similar dysplastic and malignant changes evolving, in this case in flat mucosa.

In general, then, it seems that the chances of observing dysplasia or malignancy in normal flat mucosa are very small, but are increased to clinically significant levels by the increased proliferation seen focally in adenomas or diffusely in ulcerative colitis.

\section{Conclusions}

1. There is an increased cell turnover in the large bowel mucosa of patients with ulcerative colitis whether the disease is active or in remission. 2. The abnormal proliferative pattern which persists throughout remission reflects the increased mucosal turnover and cannot be used to predict impending malignancy.

We would like to thank $\operatorname{Dr}$ B C Morson and Professor J E Lennard-Jones for their advice, Mr Christopher Magnus for his technical help, and Miss Brenda Roach for her secretarial help. EPS is supported by a grant from the Brazilian Government (CAPES); APK is supported by St. Mark's Research Foundation, and TJC is supported by a grant from the Wellcome Foundation.

\section{References}

${ }^{1}$ Morson BC, Pang LSC. Rectal biopsy as an aid to cancer control in ulcerative colitis. Gut 1967; 8:423-34.

${ }^{2}$ Lipkin M. Phase 1 and phase 2 proliferative lesions of colonic epithelial cells in diseases leading to colonic cancer. Cancer 1974; 34:878-88.

${ }^{3}$ Bleiberg H, Mainguet P, Galand P, Chretien J, Dupont-Mairesse N. Cell renewal in the human rectum. In vitro autoradiographic study on active ulcerative colitis. Gastroenterology 1970; 58:851-5.

${ }^{4}$ Eastwood GL, Trier JS. Epithelial cell renewal in cultured rectal biopsies in ulcerative colitis. Gastroenterology 1973; 64:383-90.

${ }^{5}$ Powell-Tuck J, Bown RL, Lennard-Jones JE. A comparison between oral prednisolone given as single or multiple daily doses for active proctocolitis. Scand J Gastroenterol 1978; 13:833-7.

${ }^{6}$ Lipkin M, Bell B, Sherlock P. Cell proliferation kinetics in the gastrointestinal tract of man. J Clin Invest 1963; 42:767-76.

${ }^{7}$ MacDonald WC, Trier JS, Everett NB. Cell proliferation and migration in the stomach, duodenum and rectum of man: radioautographic studies. Gastroenterology 1964; 46:405-17.

${ }^{8} \mathrm{Lieb} \mathrm{LM}$, Lisco $\mathrm{H}$. In vitro uptake of tritiated thymidine by carcinoma of the human colon. Cancer Res 1966; 26:733-40.

'Deschner EE, Lipkin M. Study of human rectal epithelial cells in vitro. J Natl Cancer Inst 1970; 44:175-85.

${ }^{10}$ Hagemann RF, Lesher S. Irradiation of the gastrointestinal tract-compensatory response of the stomach, jejunum and colon. Br J Radiol 1971; 44: 599-602.

${ }^{11}$ Morson BC. Evolution of cancer of the colon and rectum. Cancer 1974; 34:845-9.

${ }^{12}$ Hill MJ, Morson BC, Bussey HJR. Aetiology of adenoma-carcinoma sequence in large bowel. Lancet 1978; 1:245-7. 